К. Б. Рибак

\title{
СТРУКТУРА ТА СЕМАНТИКА ПОДАТКОВИХ НАЙМЕНУВАНЬ У ДАВНЬОРУСЬКОУКРАЇНСЬКІЙ МОВІ (XI-ХІІІ СТ.)
}

\begin{abstract}
Рибак К. Б. Структура та семантика податкових найменувань у давньоруськоукраїнській мові (XI-XIII ст.)

Розглянуто найменування податкової сфери у давньоруськоукраїнській мові на матеріалах пам'яток XI-XIII ст., історичних словників, що відображають лексику цього періоду. Виокремлено групи найменувань на позначення видів податків та зборів (загальні податки з населення, податки за виконання певних послуг, митний збір), суб'єктів процесу оподаткування (збирачі, платники податків) та місць збору обов'язкових платежів, проаналізовано їхнє формування та подано результати аналізу структурно-семантичних особливостей найменувань зазначеної групи слів. Зазначено, що для аналізованого історичного періоду виявився продуктивним морфологічний спосіб творення слів. Більшість найменувань походять від іменників та дієслів суфіксальним способом словотворення.
\end{abstract}

Ключові слова: податок, збір, суб'єкти оподаткування, суфіксальні форманти, конфікс, деривати.

Рыбак К. Б. Структура и семантика налоговых наименований в древнерусскоукраинском языке (XI-XIII вв.)

Рассмотрены наименования налоговой сферы в древнерусскоукраинском языке на материалах памятников XI-XIII вв., исторических словарей, отражающих лексику этого периода. Выделены группы наименований для обозначения видов налогов и сборов (общие налоги с населения, налоги за выполнение определенных услуг, таможенный сбор), субъектов процесса налогообложения (сборщики, налогоплательщики) и мест сбора обязательных платежей, проанализированы их формирования и представлены результаты анализа структурно-семантических особенностей наименований указанной группы слов. Отмечено, что для рассматриваемого исторического периода оказался продуктивным морфологический способ образования слов. Подавляющее большинство наименований происходят от существительных и глаголов суффиксальным способом словообразования.

Ключевые слова: налог, сбор, субъекты налогообложения, суффиксальные форманты, конфикс, дериваты.

Rybak K. B. Structure and semantics nominations of tax in the old-russian-ukrainian language (XI-XIII centuries)

The article devoted to the nominations of tax sphere in the old-russian-ukrainian language (XI-XIII centuries). It gives a detailed analysis of words that indicate the nominations of the process taxation. Specifically addresses the question their etymology and their division into thematic groups. Scientists studied nominations of tax, including J. Varbot, T. Krehno, V. Nimchuk, T. Tsymbal, O. Chorna etc. The attention of researchers attracted only some partial issues related titles taxes, but there are still a number of unresolved questions about the history of the formation the nominations of tax sphere in general.

() К. Б. Рибак, 2017. 
The work allocated to the following groups nominations of tax sphere: nominations of taxes (general taxes on the population, taxes on the performance of certain services, customs duties), subjects of the tax process (collectors, tax payers) and places of collection of obligatory payments. Specifically addresses the question how each nominations formed, from the words which it originates and what it means. Common features of word formation nominations of tax sphere considered. The nominations of tax sphere and fees - a lexical and semantic group in the texts of the XI-XIII centuries, which covers the types of compulsory collection of objects of taxation from the population to the state treasury or in favor of the prince for various services, including transportation of goods across the border or internal customs bonds. The nominations subjects of taxation covering vocabulary, which indicates the persons related tax issues, which are the subject of or transfer tax. Appellations of tax collection called premises, institutions or territory in which the process of direct taxation. Often, the nominations of tax sphere in this language period derived from verbs and nouns. Morphological derivation method used most often, mostly using suffixes. The nominations of tax sphere and fees occupy an important place in the history of language, as it indicates the state of development of trade and economic relations, present a social and state system and reflect the progress of mankind at a particular historical stage. The present study provides a starting-point for further research in the history of the nominations of tax sphere. The obtained results enable further investigation of the peculiarities the creation of tax nominations and their further historical analysis.

Key words: tax, capitation, subjects of taxation, suffixal formants, confix, derivatives.

Дослідники історії української мови здавна вивчають лексику, що $\epsilon$ найактуальнішою для життєдіяльності людини, зокрема назви одягу (Г. Миронова), назви хвороб і хворобливих станів (Т. Олещук), назви страв і продуктів харчування (Г. Козирєва, В. Невойт, Н. Полякова), назви грошей і грошових одиниць (Є. Чернов), назви тварин (Н. Адамчук, Г. Одинцов), медичну термінологію (В. Бріцин, Т. Олещук) і т. ін. Важливе місце в історії мови займають найменування податкової сфери, адже вказують на стан розвитку торгово-економічних зв'язків, презентують суспільно-державний устрій та відображають прогрес людства на конкретному історичному етапі.

Окремі аспекти етимології, формування складу, словотвірної структури податкових найменувань дослідили: А. Львов (1966 р.; 1975 р.) [5; 6], Ж. Варбот (1969 р.) [2], В. Німчук (1992 р.) [8], Т. Цимбал (2004 р.) [9], Т. Крехно (2005 р.) [4], О. Чорна (2009 р.) [10]. Однак немає спеціальної праці, що розкривала б історію формування податкових найменувань у давньоруськоукраїнській мові, які залишаються важливим об'єктом наукового вивчення та потребують комплексного аналізу.

Мета дослідження - здійснити детальний аналіз податкових 
найменувань давньоруськоукраїнської мови на матеріалах широкого кола пам'яток XI-XIII ст., історичних словників, що відображають лексику цього періоду.

1. Найменування податків та зборів - лексико-семантичне поле назв податків та зборів у текстах XI-XIII ст., що охоплює види обов'язкового збору об'єктів оподаткування з населення до державної скарбниці чи на користь князя за різноманітні послуги, зокрема й перевезення товарів через кордон чи внутрішні митні застави.

1.1. Загальні податки 3 населення: кинисъ / кинсъ (1057 СлРЯ VII 127) 'майно, а також податок із цього майна'. М. Фасмер пояснює

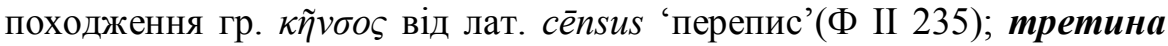
(Ізб 1073 Cp III 991) 'вид податку, третя частина чогось’; деслтина (Ізб 1076, 143-143 об. 387-388) 'вид податку, десята частина чогось'; зад ४иик (XI Cp I 908) 'внесок за упокій душі', утворено від вислову «за душу»; в tcъ (1115 СлРЯ II 110) 'податок, збір 3 певного виду зважуваного товару', в ‘c $\mathbf{b}$ - основне значення вага; дань (1130 СДЯ II 426-427) 'податок', близьке до д.-інд. danam 'дар', лат. dōnum та слов. *darъ 'дар'. Окрім того, М. Фасмер говорить про ймовірність запозичення з лтс. dãna, dãnis i, без сумніву, від лит. donis (Ф I 484); полюдиє (1130 СлРЯ XVI 288) ' 1 . Податок, що збирали 3 князівських васалів. 2. Об’їзд з метою збору’ тощо), мотивується давньоруським висловом по людьхъ (Ф ІІІ 321-322); оурокъ (1118/ 1377 ПВЛ 153) / урокъ (1150 Cp III 1258) 'податок'. Дослідник мотивує походження слова від у і реку, рок (Ф IV 168). Схожі думки висловлює П. Черних (Черных II 292-293), вказуючи на корінь *rok- (абляут до *rek-) та префікс *u-). А. Львов зазначає, що «оурок - віддієслівний іменник від оуречи» [6, с. 187-188], де оуречи 'визначати, призначати'; вира (XII СДЯ I 435-436) ‘стягування за вбивство вільної людини', якщо винний не мав грошей, аби сплатити за свою провину, за нього це робила община, яка платила різновид виры - дикага вира (1280 СДЯ I 435), клепьнага вира, поклепьнага вира (1280 436) стягувалася в разі словесного звинувачення (представлені види виры - субстантивноад'єктивні словосполучення). М. Фасмер мотивує походження вира від вирьнаг, де *вирьна 'штраф за вбивство чоловіка' могло бути похідним від прасл. відповідника лит. vyras 'чоловік' (Ф I 318); покони вирьнии (1280 СДЯ I 436) - так говорили про розміри податку на утримання вирника, субстантивно-ад'єктивне словосполучення; 
м ‘c жчьнок (XII V 112 ) 'щомісячний податок'; оброк (535) 'податок грошима чи натурою', очевидно, пов'язане із обречи 'призначити для когось щось', пор. прасл. *obrekt'i із *ob-rokb від реку (Ф III 108); повозъ (1118/1377 ПВЛ 84) 'Податок, що відвозився в назначене місце', конфіксальний дериват з афіксом по-...-Ø від везти; гамъ (1267 Cp III 1658) ‘ямська повинність, грошовий збір на ямську гонитву', від тюрк. jam - тяглова повинність, поштові коні (Ф IV 555); поборъ (1288 Cp II 987) 'податок', співвідносне 3 побрати; перекладьныи / перекладьнож (1285-1291 РПр сп. 621в) 'Податок на користь посадової особи князя', співвідносне 3 класти чи перекладати з не зовсім зрозумілим семантичним зв'язком; погородью (XIII СДЯ VI 486-487) 'податок з міст', конфіксальний дериват від городъ; подать (XIII-XIV СДЯ VI 515) співвідносне з дати (Ф I 485); забожьничьє (XIII-XIV СДЯ III 281) 'один з видів князівської данини', очевидно, назва пов'язана із божница 'церква, каплиця, храм' (Ф I 184).

1.2. Податки за виконання певних послуг - це збір, який здійснюється за реалізацію певних дій чи робіт, пов'язаних із задоволенням потреб платника: поромъ (XII СДЯ VII 222) 'податок за використання порому', пор. прасл. *рогть (ЕСУМ IV 525), пов’язане iз *perti 'рухатися, їхати', М. Фасмер підкреслює спорідненість 3 д.-ісл.

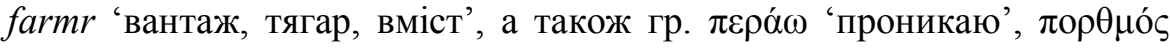
'місце переправи, переправа, переїзд’ (Ф III 331-332); вощцць (1239 СДЯ І 478) 'вид мита за торгівлю воском'; в Азъчии / вАзьбъныи (1280 СДЯ II 312) 'податок за затримання та арешт злочинця', від вжзати, тобто податок за ув’язнення злочинця; посошьныи (1285-1291 СДЯ VII 275) 'податок за отримання посади ігумена' - земельний податок від сохи (<* sоха) (ЕСУМ V 362).

1.3. Митний збір - обов'язковий платіж за переміщення через кордон товарів чи за послуги митниці: мыто /мыmb (1296 ПНЧ 22) 'збір за переміщення товарів через внутрішні застави', пор. прасл. *myto (Ф III 26) запозичення із двн. müta.

2. Найменування суб'сктів процесу оподаткування вказують на осіб, які отримують чи передають податок або збір.

2.1. Збирачі податків - уповноважені князем посадові особи, зобов'язані отримувати предмет оподаткування 3 населення та передавати до скарбниці: мытоимьць (Ізб 1076 197) 'митар', 
композитне суфіксальне утворення від мыто та нмати; възбраньникъ = возбраньникъ (XI Cp I 338) 'збирач податку', пов'язане із брати; коупьнорьвьнитель (Стих 1156-1163 72 об.) 'збирач податку', де коупьно у сполученні з іншими словами набуває значення 'спільно, разом' (<куna), у церковнослов'янському словнику подано значення күпьноревнитель як 'людина, що змагається' [4, с. 276]; ти ४нъ= тив ४нъ (XII Cp III 961-962) 'посадова особа при князю, яка виконувала різноманітні дії щодо керування містом чи місцевістю, зокрема й зі збирання податків', М. Фасмер стверджує, що слово є похідним із д.-ісл. pjónn (Ф IV 63); биричь (1229 СДЯ I 161) 'представник княжої влади', походження можливе від биръ (Ф I 167) 'податок', проте М. Фасмер зазначає, що варто шукати етимологію, виходячи із значення 'начальник' із тур. bujurudžu; коуноюмьца (1239 СДЯ IV 331) 'збирач податків', від коуна (XI/XII 330-331) 'гроші', які, до речі, мали різновиди, серед яких: коуны ветъхы $\mathbf{k}$, коуны новы $\mathbf{k}$,

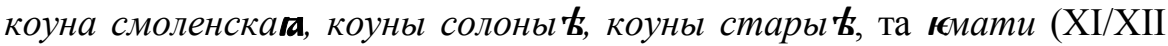
III 211-212) ‘брати’; осетрьникъ (1264 СДЯ VI 160) 'збирач податку осетрами з риболовлі'; дворлнинъ (1264-1265 СДЯ II 449-450) 'слуга князя, що виконував господарську і адміністративну роботу, зокрема займався збиранням податків'; осмьникъ (1265-1267 VI 173) 'збирач податку', похідне від осьмий «восьмий» (ЕСУМ IV 230), назва зумовлена розміром податку; баскакъ (1269 / XIII-XIV СДЯ I 105) 'обласний правитель на підкорених землях, поставлений ханом для збору дані', запозичення 3 д.-тат. мови (ЕСУМ I 148), М. Фасмер вказує, що це запозичення 3 чагат. baskak 'чиновник для збору податків із підлеглих народів' і пов'язане з тюрк. basmak 'давити'(Ф I 131); дес Атиньникъ (1280 СДЯ ІІ 458) 'Збирач десятини'; мытьникъ (РПр сп. 1280 СДЯ V 85-86) 'збирач торгового податку' та мымарь (83-84) від мызто/мыть; вирьникъ (1280 СДЯ I 436) 'посада збирача вир' (вира); даньникъ (1284 СДЯ II 161) 'збирач данини' (дань); коумеркарии (XIII СДЯ IV 327) ‘збирач податків’, пор. гр.

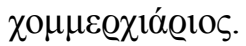

2.2. Платники податків - особи, що сплачують податок. Кілька дериватів пов'язано з дієсловом дати / давати: давьць (Ізб 1076 219) / датель (ПНЧ 129667 об.) 'той, хто дає / віддає щось', пор. прасл. *davati / *dati; даньщикъ (1267 Cp I 629) / даньникъ (1284 СДЯ II 161) 'збирач дані' від дань суфіксальним способом. Інші похідні: изполовьница (XIII СДЯ IV 69) 'платник податку, котрий віддавав () К. Б. Рибак, 2017. 
половину урожаю', від виду натурального податку изполовиє, даноплатьць (XА XI/XIII-XIV 239 б) 'той, хто платить данину', композитно-суфіксальне утворення від платити дань.

3. Найменування місць збору податків - назви на позначення установ чи територій, де відбувається процес оподаткування, зокрема: повость (947 Cp II 1017)/nогость (1268 СДЯ VI 488) 'адміністративно-податковий округ', а також 'гостинний двір, де зупинявся князь', очевидно, і для збору данини, на думку М. Фасмера nогость 'жиле подвір'я князя і його свити при оподаткуванні', пов'язано з гость, погостить (Ф III 295); мытарница (XII/ХІІІ СДЯ V 84) ‘місце збору податку' (митар) та мытьница (86) від мыть.

Зі структурного погляду для аналізованого історичного періоду виявився продуктивним морфологічний спосіб творення слів, серед яких немало давніх утворень, успадкованих українською мовою. Твірною базою для дериватів виокремленої семантичної групи служать здебільшого іменники або дієслова. Для найменувань податкової сфери розгляданого періоду характерні суфіксальні форманти -ник, -тель, -ець, -Анинъ, -ина, наприклад:

-ник: осетрьникъ (1264 СДЯ VI 160), осмьникъ (1265-1267 СДЯ VI 173), десАтиньникъ (1280 СДЯ II 458), мытьникъ (1280 СДЯ V 85), даньникъ (1284 СДЯ II 427), мьстьникъ (XII/XIII СДЯ V 99-100), які становлять словотвірний тип i мають словотвірне значення - назва особи як виконавця дії;

-тель: коупьнорьвьнитель (1156-1163 СДЯ IV 337), датель (1296 СДЯ II 433) - похідні назви осіб, суб'єктів оподаткування;

-ець: мытоимьць (Ізб 1076 197), давыць (Ізб 1076 219), даноплатьць (XIII-XIV СДЯ II 425), де суфікс додається до дієслівних основ і вказує на похідні зі значенням особи;

-Анинъ: Дворанинъ (1264-1265 СДЯ II 449-450), де суфікс вказує на особу за соціальною належністю;

-ина: деслтина (1076 СДЯ II 457-458), третина (1073 Сp III 991), де суфікс вказує на частину від цілого. Автори монографії «Нариси 3 історії українського словотворення (суфікс -ина)» називають ще ряд слів із таким суфіксом: осмина (сер. XII СДЯ V I 172) 'міра сипучих тіл, яка дорівнює восьмій частині кадi - виду посуду', седморина (Сp I II 322) 'кількість, яка складається із семи одиниць', висловлюють припущення, що таких іменників в XI-XIII ст. було більше [1, с. 38]. 
Для податкових найменувань характерний конфіксальний спосіб словотворення: за-...-иє (задУшиє (XI Cp I 908), забожьничьє (XIIIXIV СДЯ III 281), по-...-иє (полюдь (1130 СлРЯ XVI 288), почестье (1150/XVI XV 196), погородие (XIII СДЯ VI 486-487), пособие (XIII/XV СлРЯ XVII 201), конфікс по-...-Ø (ь, ь, а): поборь (1287/1425 ЛІ 299), повозъ (1118/1377 ПВЛ 84), об-...-Ф (ъ, ь): оброкъ (ХІІ СДЯ $\mathrm{V}$ 535), подъ-...- Ø (ь, а): подвода (1267 УЯ 58) [7, с. 68-93]. У творенні найменувань податкової сфери виявлено активне вживання складника конфікса по- зі значенням повторюваності чи множинності дії, процесу: поборъ (1288 Сp II 987), повозъ (1118/1377 ПВЛ 84), погородьє (XIII СДЯ VI 486-487), полюдиє (1130 СлРЯ XVI 288).

Менш продуктивною у пам'ятках XI-XIII ст. виявлено субстантивацію, наприклад, мњслчьнок (XII СДЯ V 112) 'щомісячний податок', перекладьнок (1285-1291 СДЯ VI 372) 'податок на користь посадової особи князя'. Більшість слів із загальним значенням «податкове найменування» утворюють синонімічний ряд. Деякі із досліджених найменувань є суфіксальними синонімами, наприклад: мытьникъ (1280 СДЯ V 85-86) - мытарь.

Отже, лексико-семантичне поле слів зі значенням «податкові найменування» являє собою досить розвинену історично сформовану систему слів, що характеризується активністю вживання, багатством семантики, структурною різноманітністю. Найменування податкової сфери в давньоруськоукраїнській мові (XI-XIII ст.) представлені іменниками на позначення: а) видів податків та зборів; б) платників та збирачів податків; в) місць процесу оподаткування. Більшість аналізованих іменників мають праслов'янське походження, утворені переважно морфологічним способом. Базою для творення нових слів слугують в основному іменники та дієслова. Результати дослідження за письмовими джерелами XI-XIII ст. не розкривають історії становлення лексико-семантичної системи податкових найменувань загалом, проте дають змогу простежити зв'язок формування найменувань податкової сфери від праслов'янського мовного періоду до староукраїнської мови (XIV-XVIII ст.) та динаміку їхнього функціонування при неоднакових соціально-економічних умовах.

\section{Література}

1. Білоусенко П. І. Нариси 3 історії українського словотворення (суфікс -ина) / П. І. Білоусенко, В. В. Німчук. - Запоріжжя-Ялта-Київ : ТОВ «ЛІПС» ЛТД, 2009. - 252 с.

2. Варбот Ж. Ж. Древнерусское именное словообразование / Ж. Ж. Варбот. - М. : с С. К. Б. Рибак, 2017. 
Наука, 1969. - 231 с.

3. Дьяченко Г. М. Полный церковнославянский словарь / Г. М. Дьяченко. - М. : ИО Московского Патриархата, 1993. - 1158 с.

4. Крехно Т. І. Історія лексико-семантичної групи «плати - податки - повинності» в українській мові XV-XVIII століть (на матеріалах українських пам'яток) : автореф. дис.... канд. філол. наук / Т. І. Крехно. - Х., 2005. - 19 с.

5. Львов А. С. Лексика «Повести временных лет» /А. С. Львов. - М. : Наука, 1975. -367 c.

6. Львов А. С. Очерки по лексике памятников старословянской письменности / А. С. Львов. - М. : Наука, 1966. -320 с.

7. Нариси 3 історії українського словотворення (іменникові конфікси) П. І. Білоусенко, І. О. Іншакова, К. А. Качайло, О. В. Меркулова, Л. М. Стовбур. Запоріжжя - Кривий Ріг : ТОВ «ЛІПС» ЛТД, 2010. - 480 с.

8. Німчук В. В. Давньоруська спадщина в лексиці української мови / В. В. Німчук. - К. : Наук. думка, 1992. - 416 с.

9. Цимбал Т. Я. Еволюція поняття «податок» / Т. Я. Цимбал // Науковий вісник Національної академії ДПС України. - Ірпінь, 2004. - №2(24). - С. 141-145.

10. Чорна О. В. Українська термінологія податкової сфери : структура, функціонування, формування : автореф. дис. ... канд. філол. наук / О. В. Чорна. - К., 2009. - 18 c.

\section{ЕСУМ}

Гр 1130

Ізб 1073

Ізб 1076

ПВЛ

ПНЧ 1296

ПрЛ ХIII

РПр сп. 1280

СДЯ

СлРЯ

Стих 1156-1163

\section{Перелік умовних скорочень використаних джерел}

Етимологічний словник української мови / За ред. О. С. Мельничука : у 7 т. - Т. 1-6. - К. : Наук. думка, 1982-2012.

Грамота близько 1130 року великого київського князя Мстислава Володимировича та його сина Всеволода // Німчук В. Хрестоматія 3 історії української мови Х-ХІІІ ст. - Житомир : «Полісся», 2015. С. $172-173$.

Изборник великого князя Святослава Ярославича 1073 года. - Спб., 1880. - $266 \mathrm{c.}$

Изборник 1076 года / Под ред. С. И. Коткова. - М., 1965. - 1091 с.

Повість временних літ за Лаврентіївським списком // Полное собрание русских летописей. Т.1: Лаврентьевская и Суздальская летописи по академическому списку. - М. : Изд-во вост. л-ры, 1962. Пандекты Никона Черногорца, 1296 г., ГИМ, Син., № 836, 180 л.

Пролог «Лобковский» сентябрьской половины, 1262 г., или 1282 г., ГИМ, Хлуд., №187, 148 л.

Русская правда (пространная редакция) по списку Новгородской кормчей 1280 г. Изд.: Е. Ф. Карский, Русская правда по древнейшему списку. - Л., 1930. - С. 64-88.

Словарь древнерусского языка (XI-XIV вв.) / Гл. ред. Р. И. Аванесов. - М. : Русский язык, 1988-2013. - Т. 1-10.

Словарь русского языка XI-XVII вв. - М. : Наука, 1975-2008. Вып. 1-28.

Стихирарь, 1156-1163 гг., ГПБ, Соф., №384 
Cp

Уя

XA

$\Phi$

Черных
Срезневский И. И. Материалы для словаря древнерусского языка. СПб, 1843-1912. - Т.1-3.

Устав князя Ярослава // Древнерусские княжеские уставы XI-XV вв. / Изд. подгот. Я. Н. Щапов. - М. : Наука, 1976. - С. 91-93.

Книги врємєныга и шбразныга Гешргига мниха // Истрин В. И. Хроника Георгия Амартола в древнем славянорусском переводе. Т. І. Текст. - Петроградъ, 1920. - 612 с.

Фасмер М. Этимологический словарь русского языка : в 4 т. ; пер. с нем. О. Н. Трубачёва. - М. : Прогресс, 1986-1987.

Черных П. Я. Историко-этимологический словарь современного русского языка : в 2 т. - М. : Русский язык, 2006. - Т. 1-2.

Стаття надійшла до редакиії 23.09.2017 p. 